\title{
Continuous Casting of Small-size Austenitic Stainless Steel Billets
}

\author{
Keizo Yamada, Toshio Watanabe, Kouetsu Abe, and Kazuo Fukuda
}

\begin{abstract}
Synopsis :
$\Lambda$ process was established in which AOD-refined austenitic stainless steel melts produced from homemade molten ferronickel and ferrochromium as main raw materials were continuously cast into smallsize billets of 115 to $17.5 \mathrm{~mm}$ square. The billets were then rolled into wire rods, round bars, etc. in a single heating manner.

This paper deals with the following factors contributing to obtaining very sound small-size billets.

1) The mold level control system employing a sliding nozzle.

2) The non-oxidation casting comprizing of a long nozzle and a powder casting.

3) The electromagnetic stirring.

The causes and prevention of billet defects generated in the continuous casting of difficult-to-cast grades, Ti containing SUS 321, Cil containing XM7 and fully austenitic SUS 310, were also discussed.
\end{abstract}

\section{1. 緒}

\section{言}

ステンレス鋼の进鋳に翛しては各種の優孔た資料が発 纺されているがここれらはににスラブまたは大断面ブル 一ん老刘像にしたものが多く，200 mm 佮以下の小断面 ビレット妾対象にしたものは少ない。

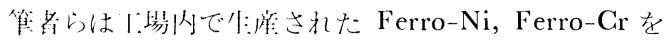
溶湯のま来条種从テンレ久鋼の原料として LD転炉で脱 理後 AOD 烦にて精鏉し， $115 \sim 175 \mathrm{~mm}$ 角の小断面鋳 胡に連鋳する技術PHA 法:1) (Pamco-Hot-Alloy 法) を確立した。ささらにこれを1ヒートで線材，丸棒などに 製品化している。この場介の速鋳時には, 鋳型内溶鋼の レベルを惟に調整して㚣定した鋳造条件を得るため タンディッショ久ライディングノズル $(\mathrm{SN})$ による溶鋼 湯酒制御を行い，さらに沓面性状向上のためにパウダ 一キャストとロンクグバルを1:体とする無酸化鋳造を実

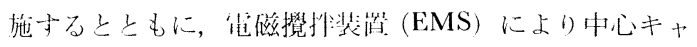
ビティの減少, 鋳造組織の微細化・等軸晶化, フェライ 卜形状の均一分散など内部品質の问上をもはかつて，従 来連錬怵難とさ机ていた $\mathrm{Ti}$ 人り, $\mathrm{Cu}$ 入りステンレス
鋼, S 快削鋼, オーステナイト単相鋼などの健全な小断 面連鋳片を得るのに成功した．本稿では主として115 $130 \mathrm{~mm}$ 角鋳片を対象にした無酸化鋳造，SN 法による 湯面制御，電磁攪找などの效果を説明し，ついでこれら の技術を使用して代表的な難鋳造鋼種である $\mathrm{Ti}$ 安定型 の SUS 321, Cu 添加の SUS XM7 およびオーステナ イト単相鋼の SUS 310 の連鋳時の問題点とその対策に ついて説明寸る.

\section{2. 操 業 法}

連鋳機はマンネスマン式垂直型のビレット，スラブ兼 用機で，ビレットサイズは前述のように 115 175 mm 角の小断面であるため, スラブや大断面ブルームに比し て操業面あるいは品質面からもトラブルが発生しやす い.このためこれら小断面連鋳に対しタンディッシュ $\mathrm{SN}$ による湯面制御，パウダーキャ大ト抢よびロング, ズルを併用した無酸化鋳造，電磁挸汼などを適用して， 鋳片品質の改善をはかることができた。

\section{$2 \cdot 1$ 鋳型内溶鋼の湯面制御}

連鋳におけるタンディッシュから鋳型への溶鋼の自動

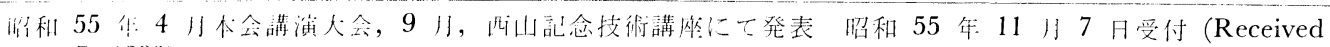
Nov. 7,1980$)$

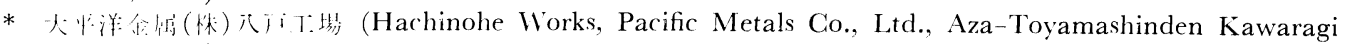
Hachinohe 031) 
注入は省力化や安定操業のみならず鋳片表面品質の改善 などの効果も期待される．溶鋼レベル検出方法としては $\gamma$ 線方式, 熱電対方式, 渦電流方式などがあるが, チュ ーブラ鋳型による小断面ビレットへの適用であるため, $\mathrm{G}_{\mathrm{S}}^{137}$ を線源とした $\gamma$ 線方式を採用し，鋳型と独立させて 設置している. この方式は放射線の鋳型内透過率の変化 を利用して溶鋼レベルを検出するものであるが，放射線 の漏洩対策と管理のために, 線源容量を小型化 $(10 \mathrm{~m}$ Ci)するとともに, 線源使用時の漏洩量を鋳型周辺, 鋳 型上いずれにおいても法定基準 $(0.6 \mathrm{mR} / \mathrm{H})$ 以下にし た.また溶鋼レベルは溶鋼注入量の制御によつてコント ロールし, 補助的に引き抜き速度を制御する方式とした。 溶鋼注入量の制御にはストッパーまたはSN が用いられ ているが，ストッパー万式は流量ゲインが大きく高精度 の位置制御を必要とする小断面連鋳には適さないため, 3 枚プレートの SN 方式を採用した. Fig. 1 に当工場 の湯面制御系構成図, Fig. 2 に $115 \mathrm{~mm}$ 角ビレット連鋳 における鋳型内湯面変動状況を示す，湯面変動域は 5〜 $7 \mathrm{~mm}$ で手動に比して明らかに小さく制御されている. 当初採用していたストッパー手動方式との直接の比較は できなかつたが，浸漬ノズルの溶損状況から判断すれば 熟練したオペレータでも湯面変動域は約 $25 \mathrm{~mm}$ と推測 され，湯面制御の優位性が認められる，表面性状におい ても湯面制御により鋳型内湯面が安定し, 従来若干認め られた鋳造パウダーの巻き込みが Fig. 3 のごとく減少

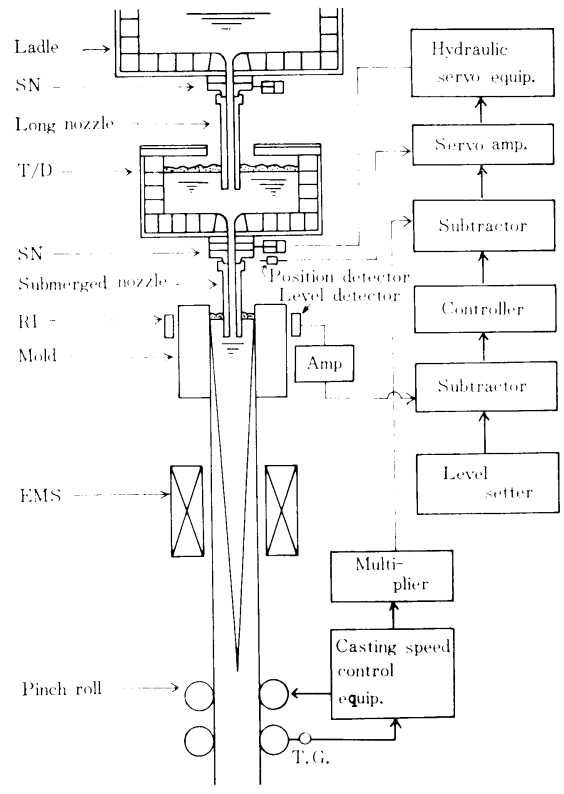

Fig. 1. Block diagram of mold level control system with sliding nozzle.
し効果をあげている。このように SN を用いた湯面制御 により，省力化はもとより衣而性状の收港がなされて操 業が安定した，反面湯面の安定化により㳇漬ノズルの局 部溶損が生じ，スラグラインの的赨性を老考隹し法け机ば ならない. SN は現在妆均 2 似以上使用しているが，さ らに使用回数を伸ばすよう改善が必要である。まだ断 面連鋳に多発する鋳造開始侍のトラブルを解沙するた め，自動鋳込み開始を可能とする検讨も必裂である。

\section{$2 \cdot 2$ 無酸化鋳造}

小断面ビレットのパウダーキャストとロングノズルを 併用した無酸化鋳造は，スラブや大断淌ブルームに比し て困難である。，只ダーキャストの效果は人父による再 酸化防止，メ二ス力又部の保温や㠜国皮膜の生成防止， 非金属介住物の吸着, シェルと鋳型間の㵎滑などがあり, 現在 $115 \mathrm{~mm}$ 角の最小ビレットまでハウダーキャストを 採用しているが，この場合メ二スカス部における浸漬， ズルの面積占有率に十分配偲し, 約 $20 \%$ 以トにして鋳 込又開始時のブリッジングを抑例することによりノズル の折損やブレークアウトを防止ししている．朴質は全鋼種

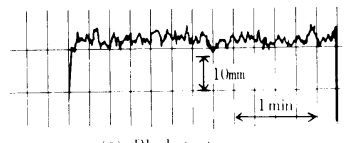

(a) Blank teis
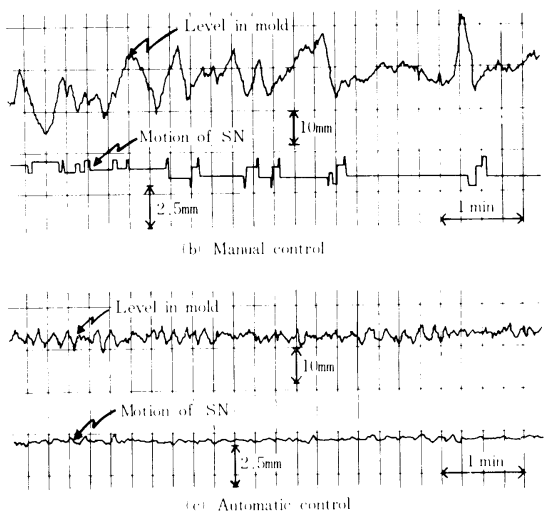

Fig. 2. Chart of mold level with sliding nozzle on the $115 \mathrm{~mm} \mathrm{sq}$. billets.

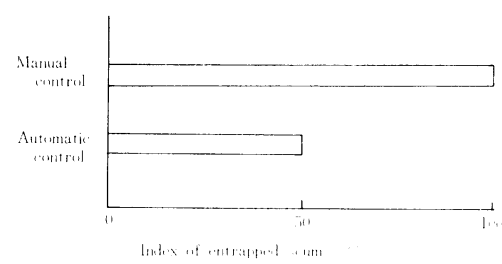

Fig. 3. Effect of level control system on the entrapped scum of small-size billets. 
Table 1. Main data of each Electromagnetic Stirrer.

\begin{tabular}{|c|c|c|c|c|}
\hline & & No. 1 Stirrer & No. 2 Stirrer & No. 3 Stirrer \\
\hline Capacity & $(\mathrm{kVA})$ & $18 \times 1$ & $50 \times 1$ & $95 \times 2$ \\
\hline Billet size & $(\mathrm{mm} \oint)$ & 115,130 & 115,130 & $\begin{array}{ll}115, & 130 \\
165, & 175 \\
\end{array}$ \\
\hline Max magnetic flux density & (gauss) & 507 & 605 & 743 \\
\hline Height of core & $(\mathrm{mm})$ & 150 & 400 & 400 \\
\hline $\begin{array}{l}\text { Position } \\
\text { (Under the meniscus) }\end{array}$ & $(\mathrm{m})$ & 4.3 & 4.5 & 4.5 \\
\hline $\begin{array}{l}\text { Number of revolution } \\
\text { (Result of } \mathrm{Hg} \text { stirring test) }\end{array}$ & $(\mathrm{rpm})$ & 590 & 790 & 860 \\
\hline Index of stirring intensity & & 1 & 3.4 & 5.8 \\
\hline
\end{tabular}

にアルミナグシファイト質を採用している。またパダ 一は比較的高粘性:域 $\left(\zeta=650 \mathrm{c}\right.$.p. at $\left.1300^{\circ} \mathrm{G}\right)$ のものを 用いており，303，321など特殊ステンレス鋼にも同一の ハウダーを使用して問題はない。一方無酸化鋳造では取 鍋ータンディッシュ閒の再酸化防止も重要であるため, 口 ングノズル泛を用いることにより，大気鋳造法では $[\mathrm{N}]$, [O] がてれぞれ 25，20 ppm 以上吸収されるのに対し， 少店くとも取鍋内溶鋼のガスレベルをタンディッシュま で保持している2). 特に後述の 321 では [N] の制御が 重要であり無酸化鋳造は不叮欠の条件である。また普通 鋼塊法と無酸化鋳造した鋳片による製品について比較す ると，非金属介侣物が $0.064 \%$ から $0.035 \%$ に半減し， 地訿水準合格燩も無酸化鋳造材が $100 \%$ であるのに対し 鋼塊材が $80 \%$ と有位着があり ${ }^{2)}$ ，無酸化鋳造した連鋳 扸が普通鋼塊法に比べて優れていることも立証できた。

\section{$2 \cdot 3$ 電磁攪找}

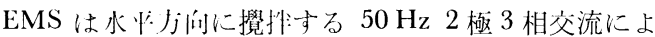
る(回転磁界ノj式を採用している。 概略仕様を Table. 1

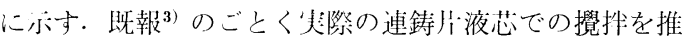
定するため水銀を用いて攪排デストを行つた。すなわち

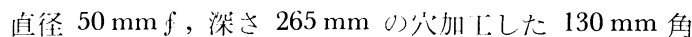
連鋳片に水銀を人机て EMS の中心にセットし，発生し た水銀洞深さを测定して（1）式により叮転数を求めた。

$$
N=(2 \cdot g \cdot J H)^{1 / 2} / d \cdot \pi
$$

ただし $N$ : 叮転数, $J H$ : 水銀洞深さ, $d$ : 水銀径

実際の連鋯では液芯断耑が円柱でないこと，粘性が一 定でないことなどから，问転数はかなり小さくなるもの と思われる。亦た攪抖力は一般に（2）式で表され，異な つた EMS の摫排力を指数比較できる.

$$
F \propto B^{2} \cdot l \cdot d^{2} \cdot f
$$

ただし $F$ : 攪排力， $B$ : 磁束密度， $d:$ 擻挥径， $f:$ 周
波数, $l$ : 攪拌有効長さ

（1）式で求めた回転数および（2）式で求めた無負荷状 態の攪找力比を Table. 1 に示す。

1〜3 号 EMS でおの沶の処理した SUS 310 鋳片の 等軸晶微細化傾向とホワイトバンド部の負偏析におよぼ す攪汼力の影響を Fig. 4 に示す。ここで No. 1 の真偏 析度を基準值の 1 としている．攪拌力の増加にともない

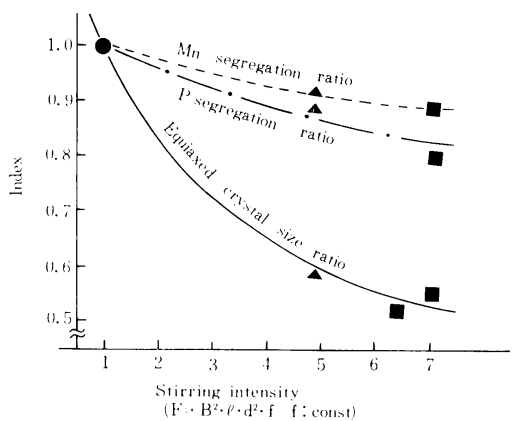

No. 1 Stirrer

A No. 2 Stirrer No. 3 Stirrer

Fig. 4. Effect of stirring intensity on the equiaxed crystal size and the segregation ratio.

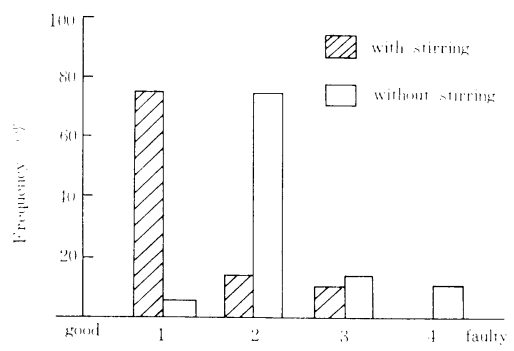

Fig. 5. Center defects improvement with No. 1 stirrer on the SUS $304130 \mathrm{~mm}$ sq. billets $(\mathrm{N}=50)$. 

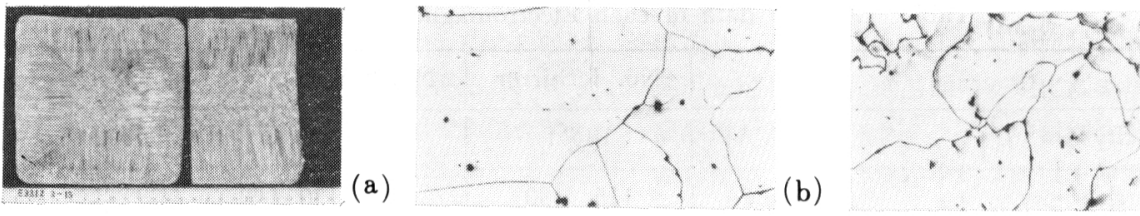

(a) Macrostructure, (b) White band ( $\times 27)$, (c) Stirred area $(\times 27)$

Photo. 1. Macro and microstructure of SUS 310.
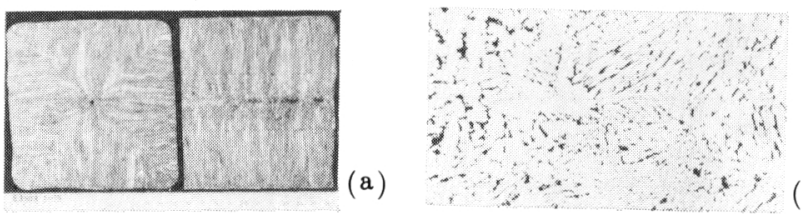

(b)

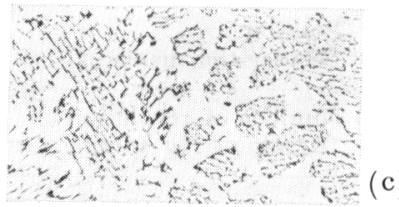

(a) Macrostructure, (b) White band ( $\times 27)$, (c) Stirred area ( $\times 27)$

Photo. 2. Macro and microstructure of SUS 308.

等軸晶は微細化するが，ホワイトバンド部の負偏析度も 強くなる傾向がみられる.

EMS による連鋳片中心欠陥の改善効果を Fig. 5 に示 すが, マク口評点で 1〜2 改善されており, 効果がうか がえる、さらに凝固組織に拈よぽす EMS の影響につい ては, Photo. 1, 2 飞示すごとく, $\gamma$ 初晶で凝固し変態 しない一次組織を示す 310 はマク口的に攪拌域が等軸晶 化し，ミク口組織も一致している. 一方 SUS 308 は $\delta$ 初晶で㠜固途中に $\gamma$ に変態した二次組織で, マクロ的に は攪拌域が微細化しているものの柱状晶も見られ，310 のような等軸晶になつていない。しかしミク口的には島 状に $\delta$ 相が形成され，これを $\gamma$ 相が井んだ等軸デンドラ イト4)になつて拉り，攪拌が十分になされていることが わかる. 308 などに残留する $\delta$ 相は熱間加工に打いて応 力の加わる方向に対し長くから直角方向に存在する場合 には有害であり5)，EMSは $\delta$ 相の方向性をなくするこ とが可能なことから，熱間加工性に対しても有効と言党 る.

\section{3. 鋳片欠宿とその対策}

前項では各種オーステナイト系ステンレス鋼の健全な
小断面ビレットを製造する諸技術を説明した，本項では Table. 2 に示すような代表的難連鋳鋼種である SUS $321 ， \mathrm{XM} 7 ， 310$ の連鋳時における問題点とその対策に ついて述べる。

\section{$3 \cdot 1$ SUS 321 (Ti 入りステンレス鋼)}

321 の連鋳に際して最も大きな問題は, $\mathrm{Ti}$ 方 $[\mathrm{O}],[\mathrm{N}]$ との親和力が強く, 生成する $\mathrm{TiO}_{2}$ あるいは $\mathrm{Ti}(\mathrm{CN})$ に よつて製品地疵欠陥あるいは鋳造時のノズル閉塞トラプ ルが発生しやすい点である. 321 圧延品に発生したへゲ をともなつた線状訿を，鋳片に発生した巻き込久欠陥と の相関性から調查したところ, Photo. 3 に示すように, 線状疵は $\mathrm{Ti}$ 系介在物を起点として発生しており, 一方 鋳片に発生した卷き込及欠陷は鋳型内で形成された $\mathrm{Ti}$ 系介在物からなるデッケル6) が凝固シェルに捕捉された ため生じたものと考兄られる。線状訿はこれらの巻き込 み欠陷が鋳片皮下に残存したまま压延されたため発生し たと推定される.

また 321 鋳造時にノズル閉塞気味になつた取鍋 SN か らの析出物を調查したところ，Table. 3 に示すように 析出物中には多量の $\mathrm{TiO}_{2}$ が含有され，X線回折では $\alpha-$ $\mathrm{Al}_{2} \mathrm{O}_{3}, \mathrm{CaO}-\mathrm{TiO}_{2}$ が検出された.

Table 2. Chemical composition of SUS 321, XM7 and 310.

\begin{tabular}{c|c|c|c|c|c|c|c|c|c|c}
\hline \multirow{2}{*}{$\begin{array}{c}\text { Grades } \\
\text { (SUS) }\end{array}$} & \multicolumn{9}{c}{ Actual Analysis (\%) } \\
\cline { 2 - 11 } & $\mathrm{C}$ & $\mathrm{Si}$ & $\mathrm{Mn}$ & $\mathrm{P}$ & $\mathrm{S}$ & $\mathrm{Cr}$ & $\mathrm{Ni}$ & $\mathrm{Mo}$ & $\mathrm{Cu}$ & $\mathrm{Ti}$ \\
\hline 321 & 0.025 & 0.40 & 1.67 & 0.020 & 0.005 & 18.71 & 10.07 & $\mathrm{Tr}$ & $\mathrm{Tr}$ & 0.35 \\
\hline $\mathrm{XM7}$ & 0.027 & 0.84 & 1.76 & 0.032 & 0.004 & 17.68 & 10.55 & 0.04 & 3.36 & \\
\hline 310 & 0.072 & 0.92 & 1.68 & 0.024 & 0.002 & 24.71 & 20.30 & 0.02 & 0.03 & \\
\hline
\end{tabular}




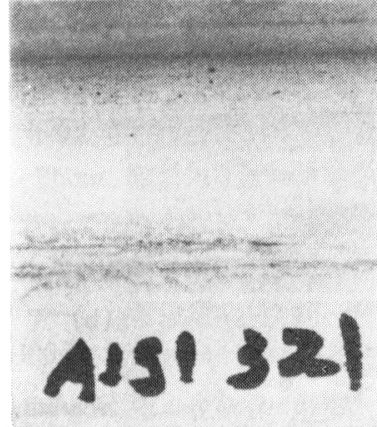

(a)

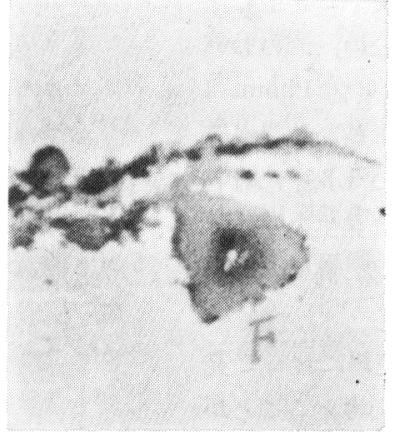

(b)

$(\times 2100)$

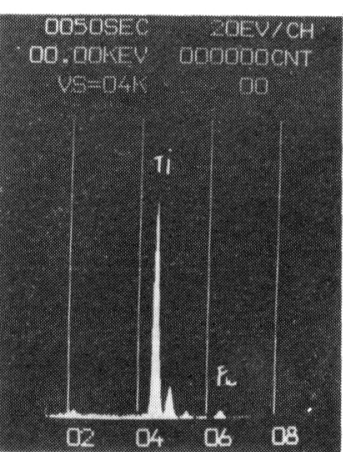

(c)

(a) Hair seam of rolled face, (b) Microstructure, (c) Result of EPMA

Photo. 3. Hair seam of SUS 321 rolled face and result of EPMA.
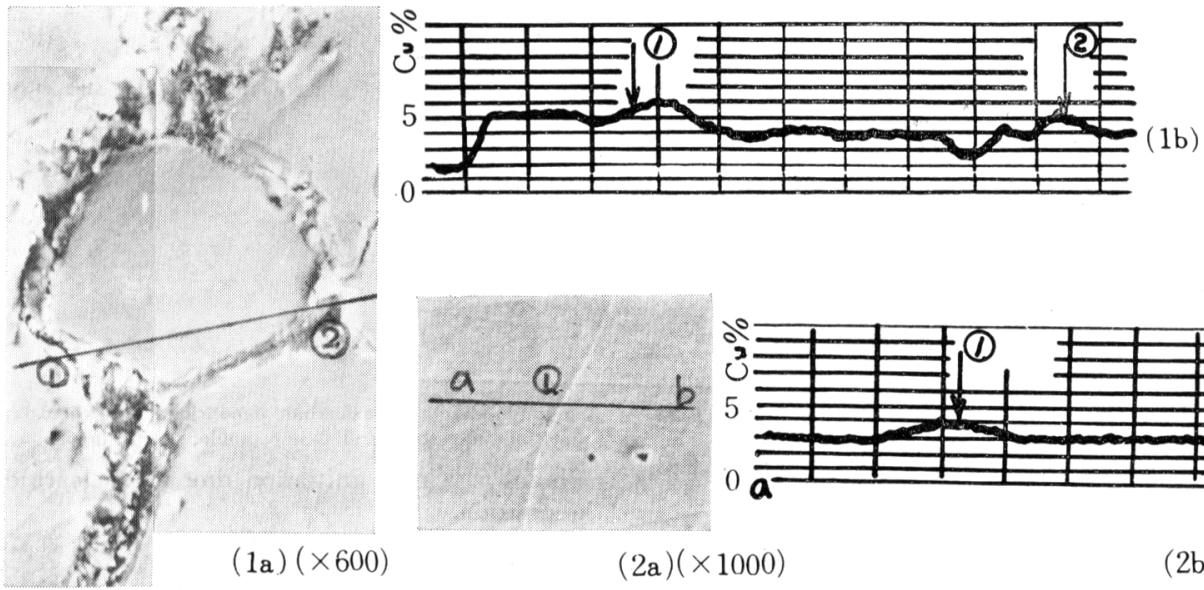

(la) Gu-enriched boundaries, (lb) Linc profile of (1) $\rightarrow$ (2) direction of $\mathrm{Cu}$

(2a) Sound boundaries, (2b) Line profile of $\mathrm{Cu}$

Photo. 4. Micrographs of SUS XM 7.

Table 3. Comparison of ladle sliding nozzle deposition.

\begin{tabular}{c|l|c|c}
\hline & Composition & $\begin{array}{c}\text { Nozzle } \\
\text { Clogging }\end{array}$ & $\begin{array}{c}\text { Normal } \\
\text { Casting }\end{array}$ \\
\hline $\begin{array}{c}\text { X-lay } \\
\text { diffraction } \\
\text { analysis }\end{array}$ & $\begin{array}{l}\alpha-\mathrm{Al}_{2} \mathrm{O}_{3} \\
\mathrm{CaO}-\mathrm{TiO}_{2}\end{array}$ & $\begin{array}{c}\text { strong } \\
\text { weak }\end{array}$ & $\begin{array}{c}\text { weak } \\
\text { strong }\end{array}$ \\
\hline & $\gamma-\mathrm{Fe}_{2} \mathrm{O}_{3}$ & - & strong \\
\hline & $\mathrm{SiO}_{2}$ & 8.9 & 5.9 \\
Chemical & $\mathrm{Al}_{2} \mathrm{O}_{3}$ & 47.0 & 50.0 \\
analysis & $\mathrm{TiO}_{2}$ & 22.8 & 0.4 \\
$(\%)$ & $\mathrm{Fe}_{2} \mathrm{O}_{3}$ & 1.8 & 15.9 \\
& $\mathrm{CaO}$ & 9.5 & 8.5 \\
& $\mathrm{MnO}$ & 3.9 & 1.7 \\
& $\mathrm{Cr}_{2} \mathrm{O}_{3}$ & 2.9 & 15.7 \\
\hline
\end{tabular}

健全な 321 鋳片を製造するには $2 \cdot 2$ で述べたように, 無酸化鋳造により $\mathrm{Ti}$ 含有溶鋼流を大気から保護し,
[Ti］の酸化，窒化による介在物の生成を防ぐことが不 可欠となる。ささらに $\mathrm{TiO}_{2}, \mathrm{Ti}(\mathrm{CN})$ 対策として精錬段 階で [Ti $] ，[\mathrm{~N}]$ 扎よび $[\mathrm{O}]$ などを低く抑光ることも 有効で，例えば PHA 法により[N]を低く抑える技術 が必要となつてくる。

\subsection{SUS XM7 (Gu 入りステンレス鋼 $)^{7)}$}

XM7 は $\mathrm{Ni}$ の一部を $\mathrm{Cu}$ で置換 $(3 \sim 4 \%)$ 乙, $\mathrm{Cu}$ のもつ展性と, 積層欠陥エネルギを上げる効果を利用し たもので，冷間加工による加工硬化性の少ない鋼種とし て賞用されている。 $\mathrm{Cu}$ はオーステナイト鋼に約 $3 \%$ ま で均一に固溶して基地を強化するが，若干じん性をそこ ない，多量に添加されると高温で粒界脆化を促進し，高 温割れに敏感になるとともに, 熱間加工性も阻害され $3^{8)}$. 
XM7 の $130 \mathrm{~mm}$ 角連鋳ビレット表面皮下に発生した 綎割れ部および同一鋳片の健全な粒界部分の，括の括の の EPMA による二次電子像と線分析結果を Photo. 4 に示す、これより, 割れはオーステナイト結晶粒界に発 生して扣り, この部分の $\mathrm{Cu}$ 值はベースの $3.3 \%$ に対し て $5 \sim 6 \%$ の高水準に濃化され，一方割れ発生のない健 全な粒界に扣いてもベース部分より 1～2\% 高い $\mathrm{Cu} の$ 濃化が生じていることがわかる。

したがつて XM7 の小断面ビレット連鋳に扔いて発 生する割れは $\mathrm{Cu}$ の粒界濃化に起因すると考光ることが できる，粒界への $\mathrm{Cu}$ の偏析濃化は, 連鋳, 特に小断面 ビレットの連鋳に扮いては, $\mathrm{Cu}$ の $\mathrm{Fe}$ に対する拡散速 度が小さいため特に顕著であると推測される.

したがつて XM7 連鋳片の割れ発生機構は次のよう に考觉ることができる。

（1）凝固にともないオーステナイト結晶粒界に $\mathrm{Cu}$ の濃化偏析相が形成される。

（2）冷却速度が速い場合，鋳造歪多が鋳片内部から の復熱により除去されないまま凝固してしまらため, 表 面層には歪みが残留する。

（3）残留歪みはオーステナイト結晶粒内と粒界に同 時に作用するが，Cu の濃化が比較的大さい脆弱な粒界 に割れが発生する.

このような $\mathrm{Cu}$ 濃化相は前述のような鋳造時の割れ発 生の久ならず，鋳片表面手入れ時に括けるいわゆるグラ インダークラックの原因となることも多い.

$\mathrm{Cu}$ の粒界濃化による割れ発生の防止には, 低温低速 鋳造を行うとともに，通常の 304 の比水率の 60 ～70\% 程度の徐冷却を実施し, 鋳片への応力集中を極力防止す る必要がある。

\subsection{SUS 310 (オーステナイト単相鋼 $)^{7}$}

代表的なオーステナイト単相鋼である 310 は $\mathrm{Ni}, \mathrm{Cr}$ が高く，耐蝕性，耐酸化性が優れた鋼で，広く耐熱用機 械部品や溶接棒素材に使用されているが，小断面連鋳に 際してはオーステナイト単相であることにより，凝固収 縮が大きく，また溶質元素の拡散速度が遅いため割れ感 受性の大きな鋼種である。

310 は初晶 $\gamma$ 相で㠜固し, 凝固過程で全く変態しない オーステナイト単相鋼であり，乙かもかなり広い凝固温 度域を有しているので, 凝固過程で低融点の不純物が液 状のまま結晶粒界に集まる。さらにこれら不純物はとの 拡散速度が $\gamma$ 相では $\delta$ 相中に比べて約 $1 / 100^{9)}$ と遅く, 310 は凝固収縮率も大きいので, 冷却中の収縮応力のも とでこの低融点相が脆弱部となり割れが発生する.

310 の $130 \mathrm{~mm}$ 角連鋳片の表面手入れ時検出された割
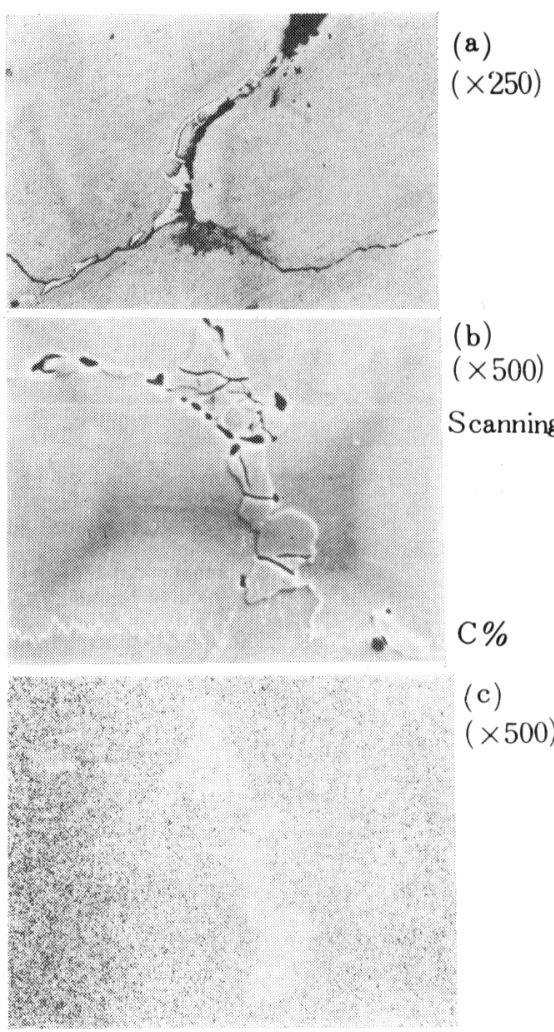

(a) Crack due to carbide deposition, (b) Micrograph of the carbide and $\mathrm{C}$ line profile, (c) $\mathrm{Cr}$ profile

Photo. 5. Crack initiation due to the carbide film deposition.

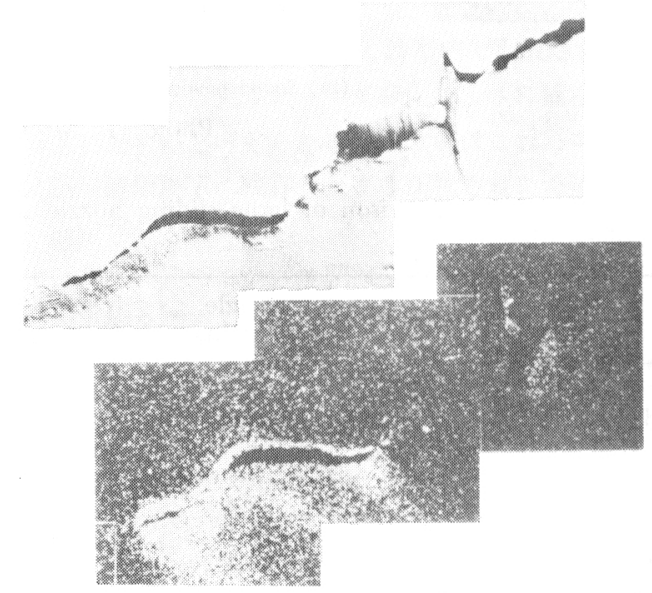

Photo. 6. Crack initiation due to the $\mathrm{Cu}$-deposition in SUS $310(\times 165)$

れ部のミクロ拈よび EPMA 二次電子像と $\mathrm{C} の$ 線分析の 結果を Photo. 5 に示す. 割れはオーステナイト結晶粒 界に沿つた析出物を起点にして発生して拉り,この析出 
物には $\mathrm{Cr} と \mathrm{C} か ゙$ 濃化され，その他に Mn の濃化も認め られるので,この析出物は $\mathrm{Cr}$ 炭化物や Mn 硫化物など の集介休と推測され，これが精界㕩れの発生源として作 用したものと考光られる。

次に Photo. 6 も鉱师・゙ラインダー眝に発生した縦割 孔部の状沉であり， 7\%にも迲与る们部的な濃化があり，鋳造時に鋳片によ つて削りとられた鋳型の Cuが，鋳片の結晶精界に沿つ て浸透したためこのような尚部的な $\mathrm{Cu}$ の濃化相が形 成されたものと考えられる。この $\mathrm{Cu}$ 濃化相は XM7で も述べたよらに機俄的に脆帩で, 割れ発生の起点となり やすい。

本䐜では 310 の鋳造割孔発生原因として C, Cr, Cu 濃化相による䊉界脆化の 2 例を述べたが， 310 に代表さ れるオ一ステナイト単相鋼は凝固特性上割れが発生しや すいため，鋳造狩には低温，低速および徐冷却などの鋳 造管理を行うとともに，鋳型のメンテナンス，スプレー

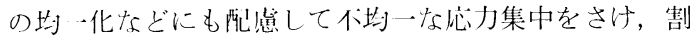
れ感受性:をさくしなければならない、鋳型からの $\mathrm{Cu}$ の没透に上る制和対策としては鋳型表面に $\mathrm{Ni}, \mathrm{Cr}$ など をふつきするう法が約果をあげている。

\section{4. 結言}

以上各種ハテンレ久鋼を対象にした小断面連鋳の操業 法と問題点拉上びその対策を説明した，省資源，省エネ ルギの汒場から考えても九棒, 形鋼, 線材など比較的大 き䒚加て比をとれる製品では, 連鋳本来の目標である 1
ヒートで製品化する連鋳片を製造することが必要と思わ れ，特に $\mathrm{Ni}, \mathrm{Cr}, \mathrm{Mo}, \mathrm{Cu}$ などの高価な合金を大量に 使用するステンレス鋼の連鋳ではその感が強い，そのた め現在，各鋼種の熱間強度，ミク口偏析などの凝固特性 に関してはまだ不明な点が多いが，今後これらの基礎的 性質を解明する必要がある。ささらにこれをもとにして湯 面制御，無酸化鋳造，電磁覮汼など連鋳技術の改善をは かることにより，小断面ビレットを対象にした 1 ヒート 压延可能鋼種の拡大を推進する必要があると思われる.

\section{交献}

1) 大半洋金愒八户：第59 回特殊鋼部会资料

2 ）山田桂三，渡部十四雄，福田和蚛，滕! 環，田 代時夫：鉄と鋼，66（1980），A25

3 ）山田桂三，渡部十四雄，福田和郎，田代時夫，篎 見健二：鉄と銅，66 (1980), S 218

4 ）竹内英魔，池原康允，柳井隆司，松村省妿：鉄と 銅，63 (1977)，p. 1287

$5) J . H$. Decroix, A. M. Neveu, and $R . J$. CAstio: Deformation under Hot Working Conditions, (1968) p. 135 [ISI Publication 108]

6 ）新日本製鉄，光：第５８回特殊鋼部会資料

7 ) 山田桂 : 第 69,70 回西山䛉念技術講座 (1980). p. 289

8 ) 長谷川正義監修, 野村茂雄: ステンレス銅便覽, (1976).p. 356 [日刊工業新聞社]

9) H. Fredriksson: Scand. J. Metallurgy, 5 (1976), p. 27 